UDK 528.481:551.24

\title{
DABARTINIŲ VERTIKALIŲJŲ ŽEMĖS PLUTOS JUDESIŲ ŠIAURĖS RYTINĖJE LIETUVOS DALYJE REGRESINIAI MODELIAI
}

\author{
Algimantas Zakarevičius, Asta Anikẻnienė \\ Geodezijos ir kadastro katedra, Vilniaus Gedimino technikos universitetas, \\ Saulètekio al. 11, LT-10223 Vilnius, Lietuva \\ El.paštas: gkk@ap.vgtu.lt
}

Iteikta 20070627 , priimta 20070927

\begin{abstract}
Santrauka. Šiaurès rytineje Lietuvos teritorijos dalyje atlikta išmatuotų vertikaliujų judesių bei kristalinio pamato reljefo ir nuosėdinès dangos geologinių rodiklių koreliacinè analizè. Nustatytas artimas koreliacinis ryšys tarp vertikaliujų Žemès paviršiaus judesių ir teritorijos geologinių, geomorfologinių rodiklių. Teritorijos tektoniniam fonui detalizuoti bei jo prognozei taikytas regresinis modelis.
\end{abstract}

Reikšminiai žodžiai: vertikalieji Žemès plutos judesiai, regresinis modelis.

\section{Ivadas}

Dabartiniai tektoniniai procesai, o kartu ir dabartiniai Žemès plutos judesiai, yra ankstesnių geologinių periodų tektoninio aktyvumo tęsinys [1,2]. Su Žemès tektoninio aktyvumo raida susiję geologiniu paviršių deformacijos, susiformavusios geologinès struktūros, nuosėdinès dangos struktūrinès ir geometrinès savybès. Išmatuotus Žemès plutos judesius galima vertinti kaip dabartinius sudètingos fizinès sistemos raidos išorinius būvio parametrus [3, 4]. Kadangi dabartiniai tektoniniai procesai yra ankstesnès Žemès tektoninès raidos tęsinys, tai ir išmatuotieji dabartiniai sistemos būvio parametrai turi būti akivaizdūs konkrečios teritorijos geologinès sandaros ir geofizinių lauku charakteristikose. Ir atvirkščiai, kai kurios geologinès, ypač tektoninès, Žemès plutos savybès gali turèti įtakos sistemos veikimo išoriniams parametrams.

Nors platforminiuose rajonuose tektoniniai judesiai yra lèti, greito poveikio geologiniu ir geomorfologiniu procesų raidai neturi, tačiau per ilgesnius laiko tarpsnius jie šiuos procesus veikia. Pagal stebimus kitus geologinius bei geomorfologinius ilgesnio laikotarpio raidos désningumus galima spręsti ir apie dabartiniu Žemès plutos judesių raidos tendencijas.

Nagrinèjant geodezinius matavimus kompleksiškai su teritorijos geologiniais, geomorfologiniais, geofiziniais ypatumais, interpretuojant daugelị požymių kaip sudetingu tarpusavio sąveiku sistema, galima taikyti matematiniais metodais pagrịstas sisteminès analizès metodikas [2, 5].

Geologinè sandara teritoriniu požiūriu yra nevienalytè, todèl sąsajų tarp geodeziniais metodais išmatuotų dabartinių Žemès plutos judesių bei teritorijos geologiniu rodikliu nustatymo ir kitus tyrimus reikia atlikti regioniniu principu. Skirtingą sąsajų pobūdị pavieniuose regionuose patvirtina ir anksčiau Lietuvos teritorijoje atlikti tyrimai [6-8].

Šio darbo tikslas - nustatyti matematines statistines sąsajas tarp vertikaliujų Žemès plutos judesių greičių ir jomis remiantis sudaryti Žemés plutos judesių modelį dabartiniam tektoniniui fonui prognozuoti.

Tyrimo objektas - Šiaurès Rytų Lietuvos regionas. Šiame Rytų Lietuvos regione geodeziniais matavimais nustatyti intensyvūs dabartiniai Žemès plutos judesiai [1, 2, 5, 9] bei judesių krypties inversijos einant laikui. Šiame regione tirti dabartinius geodinaminius procesus labai aktualu ir praktiniu požiūriu vertinant Ignalinos $\mathrm{AE}$ aplinkos geodinaminio bei seisminio pobūdžio riziką $[7,8]$.

Tyrimų metodas - išmatuotų Žemès plutos judesių ir teritorijos geologinių rodiklių koreliacinè bei regresinè analizè.

Tyrimo rezultatų naujumas - patikslintos tiriamojo regiono dabartinių vertikaliujų Žemès plutos judesių charakteristikos ir nustatytos matematinès statistinès juc sąsajos su teritorijos geologinès sandaros ypatumais, sudarytas vertikaliujuc Žemès plutos judesių prognozavimo regresinis modelis.

\section{Išmatuotų vertikaliųjų Žemès plutos judesių greičiai}

Šiaurès rytinejje Lietuvos dalyje dabartinių vertikaliųjų Žemès plutos judesių greičiams apskaičiuoti remtasi 1935, 1936, 1948, 1968, 1970, 1971, 1980, 1985, 1987, 1998, 2005, 2006 metu precizinio niveliavimo rezultatais. Vertikaliujų judesių tarp gretimų reperių sąlyginiai greičiai pradinio trasos taško atžvilgiu apskaičiuoti pagal [9] darbe pateiktus algoritmus.

Atlikus matematinę statistinę šio regiono matavimo rezultatų analizę, nustatyta, kad vertikaliujų Žemės plutos 
judesių greičių kaitos amplitudè siekia iki 4-6 mm per metus, taip pat su ne mažesne nei $p=0,95$ tikimybe nustatyta, kad einant laikui keičiasi vertikaliujų Žemès plutos judesių greičiu kryptis: Turmanto - Vilniaus linijoje 2005-2006-1985-1987 m. bei 1985-19871968 m., Jonavos - Zarasu - Turmanto linijoje 20051980 m. bei 1980 - 1935-1936 m. ir linijoje Vilnius Jonava 1998-1970-1971 ir 1970-1971-1948 m. laiko tarpais vertikaliujų judesių kryptys yra priešingos [9].

Atsižvelgdami i tai, kad nustatyta vertikaliuju Žemès plutos judesių savybių kaita einant laikui, nagrinejjamosios teritorijos Žemès plutos judesiu modeliui sudaryti naudosime paskutiniujuc dviejų geodezinių matavimų ciklų rezultatus.

\section{Vertikaliųjų Žemès plutos judesių greičių ir teritorijos geologinių rodiklių koreliacinès priklausomybès}

Tiriant vertikaliujų Žemès plutos judesių sąsajas su teritorijos geologiniais rodikliais, atsižvelgiama i šiuos teritoriją apibūdinančius rodiklius, su kuriais ieškoma dabartinių vertikaliujų Žemès paviršiaus judesių v sąsajų:

$\mathrm{x}_{1}$ - gravitacinis laukas;

$\mathrm{x}_{2}$ - magnetinis laukas;

$\mathrm{x}_{3}-$ dabartinis Žemès paviršiaus reljefas;

$\mathrm{x}_{4}-$ kristalinio pamato reljefas;

$\mathrm{x}_{5}$ - prekvartero (pagrindinių sluoksnių) reljefas;

$\mathrm{x}_{6}-$ kvartero dangos storis;

$\mathrm{x}_{7}-$ nuosédinès dangos storis; storis.

$\mathrm{x}_{8}-$ prekvartero (pagrindinių sluoksnių) dangos

Geologinių rodiklių ir vertikaliujų Žemès plutos judesių tarpusavio sąsajos apibūdinamos koreliacijos koeficientu matrica [10]:

$$
K=[k]=\frac{1}{n-1} Q^{T} Q
$$

čia $Q$ - centruotoji ir normuotoji pradinių duomenu matrica; $T$ - matricos transponavimo simbolis, $n-$ pakartotinai niveliuotų reperių skaičius.

Tiriant vertikaliujų Žemès paviršiaus judesių sąsajų su geologiniais rodikliais ypatumus, apskaičiuotos koreliacinès matricos linijose Vilnius - Jonava (19981970 m.); Jonava - Zarasai - Turmantas (20051980 m.); Turmantas - Vilnius (2005/06-1985/87 m.) bei šias linijas sujungiant ị visumą.
Kaip pradiniai duomenys, skaičiuojant koreliacines matricas minètose niveliacijos linijose, apskaičiuotos reperiu judesiu greičių reikšmès paimtos iš [9] darbo, o geologinių rodiklių reikšmès nustatytos pagal reperių koordinates iš skaitmeninès duomenų bazès.

Išmatuotų vertikaliujų Žemès paviršiaus judesių greičiu koreliacijos su teritorijos geologiniais rodikliais koeficientai pateikti 1 lentelèje.

Iš lentelèje pateiktų duomenų analizès matyti, kad stipriausi vertikaliujų Žemès plutos judesių koreliaciniai ryšiai linijoje Vilnius - Jonava yra su visais geologiniais rodikliais, išskyrus gravitacinị lauką bei magnetinị lauką, kurių koreliacijos koeficientai $R \leq 0,25$. Linijoje JonavaZarasai - Turmantas stipriausi koreliaciniai ryšiai su dabartiniu Žemès paviršiaus reljefu, kvartero dangos storiu bei prekvartero (pagrindinių sluoksnių) reljefu, $R \geq 0,62$. Linijoje Turmantas - Vilnius stipriausi vertikaliujų Žemès plutos judesių koreliaciniai ryšiai yra su gravitaciniu lauku, dabartiniu Žemès paviršiaus reljefu, kristalinio pamato reljefu, nuosėdinès dangos storiu bei prekvartero (pagrindiniu sluoksnių) dangos storiu $-0,94 \leq R \leq 0,95$. Sujungus visas linijas i bendra uždarą poligoną stipriausi koreliaciniai ryšiai yra su gravitaciniu lauku, kristalinio pamato reljefu, prekvartero (pagrindinių sluoksnių) reljefu, nuosėdinès dangos storiu bei prekvartero (pagrindinių sluoksniu) dangos storiu $-0,69 \leq R \leq 0,70$.

\section{Regresinio modelio sudarymo metodika}

Pagal matematinès statistinès vertikaliujų Žemès paviršiaus judesių analizès rezultatus nustatyta, kad yra koreliacinis ryšys tarp dabartinių vertikaliuju Žemés plutos judesių ir teritorijos geologinių bei geofiziniu rodiklių. Galima teigti, kad dabartiniai Žemès plutos judesiai Šiaurès rytineje Lietuvos dalyje yra natūrali geologinių procesu raidos tąsa, o tai reiškia, kad yra reali galimybė pagal teritorijos geologinius bei geofizinius rodiklius prognozuoti pagrindinius nūdienos tektoninių procesų vyksmo bruožus, apibūdinti dabartini tektoninị foną.

Teritorijos tektoninio fono prognozei galima taikyti regresinį modeli. Turint pakartotinų niveliacijų linijų reperių išmatuotų vertikaliujų judesių [9] (jie sutapatinami su Žemès paviršiaus judesiais) duomenis ir minètujų teritorijos geologinių rodiklių skaitmenines reikšmes, galima sudaryti regresinị modelị:

1 lentelè. Vertikaliụų Žemès paviršiaus judesių greičių bei geologinių rodiklių koreliacija

Table 1. The correlation of the vertical Earth's surface movements with the geological rates

\begin{tabular}{|l|l|l|l|l|l|l|l|l|}
\hline Linija/ poligonas & $r\left(v x_{1}\right)$ & $r\left(v x_{2}\right)$ & $r\left(v x_{3}\right)$ & $r\left(v x_{4}\right)$ & $r\left(v x_{5}\right)$ & $r\left(v x_{6}\right)$ & $r\left(v x_{7}\right)$ & $r\left(v x_{8}\right)$ \\
\hline Vilnius - Jonava & 0,25 & 0,07 & 0,89 & 0,88 & 0,77 & 0,64 & $-0,85$ & $-0,85$ \\
\hline Jonava - Zarasai - Turmantas & 0,31 & $-0,11$ & 0,89 & 0,12 & 0,80 & 0,62 & 0,44 & 0,32 \\
\hline Turmantas - Vilnius & $-0,86$ & $-0,31$ & 0,69 & $-0,94$ & 0,22 & 0,45 & 0,93 & 0,95 \\
\hline $\begin{array}{l}\text { Vilnius - Jonava - Zarasai - } \\
\text { Turmantas - Vilnius }\end{array}$ & $-0,69$ & 0,02 & 0,29 & $-0,57$ & 0,45 & $-0,03$ & 0,70 & 0,67 \\
\hline
\end{tabular}




$$
V=\beta X+\varepsilon,
$$

čia $V$ - išmatuotų vertikaliujų Žemès paviršiaus judesių reikšmių vektorius; $X$ - teritorijos geologiniu rodikliu skaitmeninių reikšmių matrica; $\beta$ - modelio parametru vektorius; $\varepsilon$ - atsitiktiniu paklaidų vektorius.

Modelio parametrai (2) nustatomi mažiausiuju kvadratų metodu $[1,2,10]$. Jų reikšmès:

$$
b=\left(X^{T} X\right)^{-1} X^{T} V
$$
rašyti

Tuomet empiriškai nustatytą regresini modeli galima

$$
\hat{V}=b X
$$

Regresinio modelio adekvatumas matavimo rezultatams tikrinamas taikant determinacijos koeficientą $R^{2}$ ir Fišerio $F$ statistiką.

Determinacijos koeficiento

$$
R^{2}=\frac{b^{T} X^{T} V-n \bar{V}^{2}}{V^{T} Y-n \bar{V}^{2}}
$$

kitimo ribos $-0 \leq R^{2} \leq 1$. Šis koeficientas byloja apie regresinio modelio efektyvumą. Kuo determinacijos koeficientas artimesnis vienetui, tuo regresinis modelis geriau atitinka matavimo rezultatus.

Determinacijos koeficientas rodo santyki tarp išmatuotų ir regresijos modeliu aprašytų vertikaliujų Žemès paviršiaus judesių reikšmių. Determinacijos koeficientą padauginę iš 100, gausime procentais išreikštą rodikli, kuris rodo, kokią išmatuotų dydžių dali iॄvertina regresinis modelis.

Vertinant sudaryto regresinio modelio adekvatumą nagrinėjamoje trasoje išmatuotiems vertikaliujuc Žemès

2 lentelè. Regresinès analizès rezultatai

Table 2. The results of the regression analysis plutos judesių greičiams taip pat skaičiuojama $F$ statistika:

$$
F=\frac{\left(b^{T} X^{T} V-n \bar{V}^{2}\right)(n-m-2)}{\left(V^{T} V-b X^{T} V\right)(m-1)},
$$

čia $n$ - geodezinių ženklų (išmatuotų judesių greičiu) skaičius, $m$ - regresinio modelio parametrų skaičius.

Statistika $F$ turi $k_{1}=m-1$ ir $k_{2}=n-m-2$ laisvès laipsnius. Jeigu $F>F_{q\left(k_{1}, k_{2}\right)}$, tai su tikimybe $p=1-q$ galima teigti, $\mathrm{kad}$ regresinis modelis adekvatus išmatuotiems dydžiams ir įvertina $100 R^{2}, \%$, išmatuotų vertikaliujų Žemès paviršiaus judesių reikšmių.

Atliekant tyrimus, taikyti tiesiniai regresiniai modeliai

$$
\hat{V}=b_{0}+b_{1} x_{1}+b_{2} x_{2}+\ldots+b_{n} x_{n}
$$

Regresiniai modeliai skaičiuoti trim būdais:

1) taikant visus koreliacinei analizei naudotus geologinius rodiklius;

2) atsižvelgiant tik i tuos teritoriją apibūdinančius rodiklius, kurių koreliacijos su vertikaliujų Žemès plutos judesiu greičiais koeficiento reikšmė $r \geq 0,50$;

3) taikant atvirkštinę žingsninę regresiją, kol regresijos lygtyje lieka 2-4 didžiausiają įtaką turintys rodikliai, esant pakankamos tikimybès modelio adekvatumo rodikliams.

Gauti pavienių nagrinètų linijų bei šių linijų, sujungtų i vieną uždarą poligoną, tiesiniai regresijos modeliai ir jų adekvatumo matavimo rezultatams

\begin{tabular}{|c|c|c|c|c|c|c|c|c|c|c|c|c|}
\hline \multirow{3}{*}{$\begin{array}{l}\text { Eil. } \\
\text { nr. }\end{array}$} & \multirow{3}{*}{$\begin{array}{l}\text { Analizès } \\
\text { žingsniai }\end{array}$} & \multicolumn{8}{|c|}{ Geologiniai rodikliai } & \multirow{2}{*}{$R^{2}, \%$} & \multirow[t]{2}{*}{$F$} & \multirow{2}{*}{$\begin{array}{c}F_{q\left(k_{1}, k_{2}\right)} \\
q=0,05\end{array}$} \\
\hline & & $\mathrm{x}_{1}$ & $\mathrm{x}_{2}$ & $\mathrm{x}_{3}$ & $\mathrm{x}_{4}$ & $\mathrm{x}_{5}$ & $\mathrm{x}_{6}$ & $\mathrm{x}_{7}$ & $\mathrm{x}_{8}$ & & & \\
\hline & & \multicolumn{11}{|c|}{ Vilnius - Jonava } \\
\hline 1 & 1 & $x$ & $x$ & $x$ & $x$ & $x$ & $x$ & $x$ & $x$ & 96,21 & 15,87 & 4,82 \\
\hline 2 & 2 & & & $x$ & $x$ & $x$ & $x$ & $x$ & $\times$ & 94,84 & 21,46 & 3,87 \\
\hline 3 & 3 & & & $x$ & $x$ & & $x$ & $x$ & & 92,85 & 29,24 & 3,63 \\
\hline \multicolumn{13}{|c|}{ Jonava - Zarasai - Turmantas } \\
\hline 4 & 1 & $x$ & $x$ & $x$ & $x$ & $x$ & $x$ & $x$ & $x$ & 92,23 & 25,21 & 2,55 \\
\hline 5 & 2 & & & $x$ & & $x$ & $x$ & & & 80,27 & 29,84 & 3,05 \\
\hline 6 & 3 & & $x$ & & $x$ & $x$ & & $x$ & & 91,03 & 53,29 & 2,84 \\
\hline \multicolumn{13}{|c|}{ Turmantas - Vilnius } \\
\hline 7 & 1 & $x$ & $x$ & $x$ & $x$ & $x$ & $x$ & $x$ & $x$ & 96,14 & 52,95 & 2,55 \\
\hline 8 & 2 & $x$ & & $x$ & $x$ & & & $x$ & $x$ & 96,00 & 96,04 & 2,71 \\
\hline 9 & 3 & $x$ & & & & & $x$ & & $x$ & 96,05 & 178,37 & 3,05 \\
\hline \multicolumn{13}{|c|}{ Vilnius - Jonava - Zarasai - Turmantas - Vilnius } \\
\hline 10 & 1 & $x$ & $x$ & $x$ & $x$ & $x$ & $x$ & $x$ & $x$ & 81,00 & 30,90 & 2,06 \\
\hline 11 & 2 & $x$ & & & $x$ & $\times$ & & $x$ & $\times$ & 76,20 & 39,06 & 2,35 \\
\hline 12 & 3 & $x$ & & & & $x$ & & $x$ & & 75,40 & 64,38 & 2,73 \\
\hline
\end{tabular}
rodikliai.

Regresiniu modeliu adekvatumui ịvertinti apskaičiuotas determinacijos koeficientas $R^{2}, \%$, statistika $F$ bei $F_{q\left(k_{1}, k_{2}\right) q=0,05}$ (2 lentelé; regresijos modeliai - 3 lentelè). 
Iš 2 lentelèje pateiktų duomenų galima daryti išvadą, kad, regresiniams modeliams sudaryti naudojant tik tuos geologinius rodiklius, kurių koreliacijos su vertikaliujuc Žemès plutos judesiu greičiais koeficientas $r \geq 0,50$, arba taikant atvirkštinès žingsninès regresijos metodiką, galima sumažinti regresijos lygties kintamujuc skaičių, iskaitant beveik tuos pačius regresinio modelio adekvatumo matavimo rezultatams rodiklius. Niveliavimo linijų Jonava - Zarasai - Turmantas ir Turmantas - Vilnius modelio adekvatumo rodikliai visais trim atvejais išlieka iš esmès tie patys. Linijos VilniusJonava, kurios Žemès plutos judesių greičių sklaida nedidelè (amplitudè iki $0,7 \mathrm{~mm}$ ir yra apie 5 kartus mažesnè negu kitų linijų), taikant lygtyje mažiau kintamujuc, modelio adekvatumas pirmais dviem atvejais išlieka iš esmès tas pats, o žingsninès regresijos atveju sumažèja apie $15 \%$, tačiau išlieka pakankamai geras (determinacija apie $83 \%$ ). Regresijos lygtyse sumažinti kintamujuc skaičiu be didelio nuostolio modeliu adekvatumui galima dèl to, kad teritoriją apibūdinantys rodikliai tarpusavyje taip pat statistiškai priklausomi, t. y. vertikalieji Žemès paviršiaus judesiai ir geologiniai teritorijos rodikliai tos pačios sudètingos fizinès sistemos, kurią veikia tektoninès įtampos, išoriniai būvio parametrai. Skirtumas tik tai, kad geologiniai rodikliai byloja apie ilgą geologinès raidos laikotarpi, o dabartiniai Žemès plutos judesiai - paskutiniuosius dešimtmečius.

Nevienodas geologinių rodiklių pasiskirstymas pavienèse linijose antrajame bei trečiajame analizès variantuose patvirtina, kad sasajos tarp geologiniu rodiklių ir Žemès plutos judesių ne visur vienodos. Todèl nagrinèjant šiuo požiūriu dideles teritorijas, būtina išsamią analizę atlikti teritoriniu principu, atsižvelgiant i geologinę sandarą.

Uždarojo poligono Vilnius - Jonava - Zarasai Turmantas - Vilnius regresinių modelių (3 lentelè) adekvatumo matavimo duomenims rezultatai kiek prastesni nei pavienių linijų, tačiau visais atvejais determinacija yra didesnè kaip 75\%. Dispersinès analizès rezultatai rodo, kad ir pavieniu linijų, ir uždaro poligono visų modeliu bei matavimo duomenų atitikimo tikimybè $p \geq 0,95$.

3 lentelè. Regresijos modeliai

Table 3. Regression models

\begin{tabular}{|c|c|c|}
\hline $\begin{array}{l}\text { Eil. } \\
\text { nr. }\end{array}$ & $\begin{array}{l}\text { Regresinès } \\
\text { analizès } \\
\text { žingsniai }\end{array}$ & \multirow[t]{2}{*}{ Regresijos modeliai } \\
\hline & & \\
\hline 1 & 1 & $\begin{array}{l}\hat{V}=3,327-0,625 \cdot 10^{-2} \cdot x_{1}-0,887 \cdot 10^{-2} \cdot x_{2}-7,122 \cdot 10^{-2} \cdot x_{3}+9,530 \cdot 10^{-2} \cdot x_{4}- \\
3,532 \cdot 10^{-2} \cdot x_{5}+3,092 \cdot 10^{-2} \cdot x_{6}+3,560 \cdot 10^{-2} \cdot x_{7}+5,509 \cdot 10^{-2} \cdot x_{8}\end{array}$ \\
\hline 2 & 2 & $\begin{array}{l}\hat{V}=2,914-7,705 \cdot 10^{-2} \cdot x_{3}+10,016 \cdot 10^{-2} \cdot x_{4}-3,148 \cdot 10^{-2} \cdot x_{5}+3,297 \cdot 10^{-2} \cdot x_{6}+ \\
3,846 \cdot 10^{-2} \cdot x_{7}+5,757 \cdot 10^{-2} \cdot x_{8}\end{array}$ \\
\hline 3 & 3 & $\hat{V}=4,424-8,667 \cdot 10^{-2} \cdot x_{3}+7,315 \cdot 10^{-2} \cdot x_{4}+0,953 \cdot 10^{-2} \cdot x_{6}+6,739 \cdot 10^{-2} \cdot x_{7}(10)$ \\
\hline \multicolumn{3}{|r|}{ Jonava -Zarasai-Turmantas } \\
\hline 4 & 1 & $\begin{array}{l}\hat{V}=8,431+1,723 \cdot 10^{-2} \cdot x_{1}-7,961 \cdot 10^{-2} \cdot x_{2}-0,0956 \cdot 10^{-2} \cdot x_{3}+8,170 \cdot 10^{-2} \cdot x_{4}- \\
4,226 \cdot 10^{-2} \cdot x_{5}-3,964 \cdot 10^{-2} \cdot x_{6}+8,170 \cdot 10^{-2} \cdot x_{7}-1,458 \cdot 10^{-2} \cdot x_{8}\end{array}$ \\
\hline 5 & 2 & $\hat{V}=-1,499+7,895 \cdot 10^{-2} \cdot x_{3}-4,980 \cdot 10^{-2} \cdot x_{5}-4,709 \cdot 10^{-2} \cdot x_{6}$ \\
\hline 6 & 3 & $\hat{V}=8,055-9,275 \cdot 10^{-2} \cdot x_{2}+5,597 \cdot 10^{-2} \cdot x_{4}-1,685 \cdot 10^{-2} \cdot x_{5}+4,193 \cdot 10^{-2} \cdot x_{7}(13)$ \\
\hline \multicolumn{3}{|r|}{ Turmantas - Vilnius } \\
\hline 7 & 1 & $\begin{array}{l}\hat{V}=-5,579-5,104 \cdot 10^{-2} \cdot x_{1}+5,247 \cdot 10^{-2} \cdot x_{2}-0,776 \cdot 10^{-2} \cdot x_{3}+2,159 \cdot 10^{-2} \cdot x_{4}- \\
1,617 \cdot 10^{-2} \cdot x_{5}-2,726 \cdot 10^{-2} \cdot x_{6}-2,020 \cdot 10^{-2} \cdot x_{7}+5,679 \cdot 10^{-2} \cdot x_{8}\end{array}$ \\
\hline 8 & 2 & $\begin{array}{l}\hat{V}=-5,378-5,065 \cdot 10^{-2} \cdot x_{1}-1,436 \cdot 10^{-2} \cdot x_{3}+0,880 \cdot 10^{-2} \cdot x_{4}-3,727 \cdot 10^{-2} \cdot x_{7}+ \\
6,070 \cdot 10^{-2} \cdot x_{8}\end{array}$ \\
\hline 9 & 3 & $\hat{V}=-5,846-4,976 \cdot 10^{-2} \cdot x_{1}-4,976 \cdot 10^{-2} \cdot x_{6}+1,451 \cdot 10^{-2} \cdot x_{8}$ \\
\hline \multicolumn{3}{|r|}{ Vilnius - Jonava - Zarasai - Turmantas - Vilnius } \\
\hline 10 & 1 & $\begin{array}{l}\hat{V}=-7,669-3,189 \cdot 10^{-2} \cdot x_{1}-1,627 \cdot 10^{-2} \cdot x_{2}+10,046 \cdot 10^{-2} \cdot x_{3}-8,160 \cdot 10^{-2} \cdot x_{4}+ \\
1,252 \cdot 10^{-2} \cdot x_{5}+2,213 \cdot 10^{-2} \cdot x_{6}-10,399 \cdot 10^{-2} \cdot x_{7}+3,093 \cdot 10^{-2} \cdot x_{8}\end{array}$ \\
\hline 11 & 2 & $\begin{array}{l}\hat{V}=-6,562-3,333 \cdot 10^{-2} \cdot x_{1}-0,251 \cdot 10^{-2} \cdot x_{4}+3,405 \cdot 10^{-2} \cdot x_{6}+1,390 \cdot 10^{-2} \cdot x_{7}- \\
0,909 \cdot 10^{-2} \cdot x_{8}\end{array}$ \\
\hline 12 & 3 & $\hat{V}=-5,590-3,689 \cdot 10^{-2} \cdot x_{1}+3,147 \cdot 10^{-2} \cdot x_{5}+0,667 \cdot 10^{-2} \cdot x_{7}$ \\
\hline
\end{tabular}


Išmatuotų vertikaliujų Žemės plutos judesių greičiai ir prognozavimo rezultatai pagal visu triju tipu regresinius modelius niveliacijuc linijose (Vilnius Jonava, Jonava - Zarasai - Turmantas, Turmantas Vilnius) pavaizduoti 1-3 paveiksluose. Poligone Vilnius Jonava - Zarasai - Turmantas - Vilnius - 4 paveiksle.

Iš 1-4 paveikslų matyti, kad visi regresijos modeliai pakankamai gerai atspindi matavimų rezultatus. Modeliai gauti visais trim nagrinètais būdais, labai nedaug skiriasi ir atspindi bendruosius dèsningumus. Modeliai, sudaryti taikant tik rodiklius, kurių koreliacijos su vertikaliuju Žemès plutos judesių greičiais koeficientu reikšmės $r \geq 0,50$, bei žingsninę regresiją, geriau eliminuoja lokaliąsias išmatuotų reikšmių anomalijas, t. y. pagal juos gaunami labiau apibendrinti prognozavimo rezultatai.

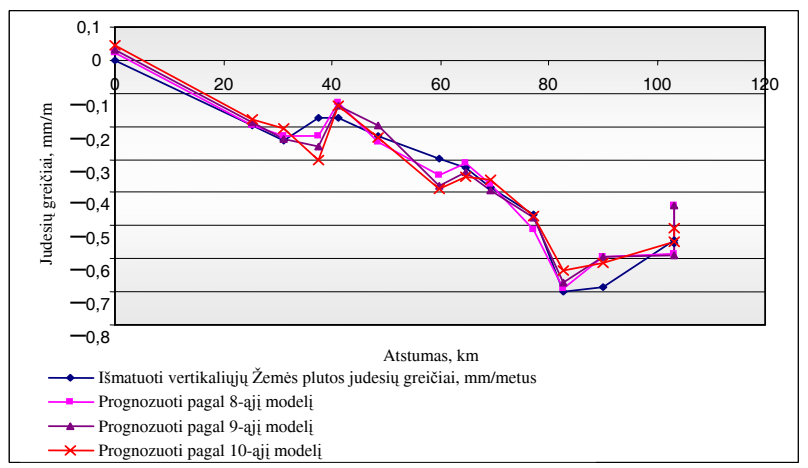

1 pav. Išmatuotų ir prognozuotų vertikaliujų Žemès plutos judesių linijoje Vilnius - Jonava grafikas (pagal 1998-1970 m. matavimo duomenis)

Fig 1. The graphs of measured and forecasted vertical earth crust movements at a line of Vilnius - Jonava (according to the data of 1998-1970)

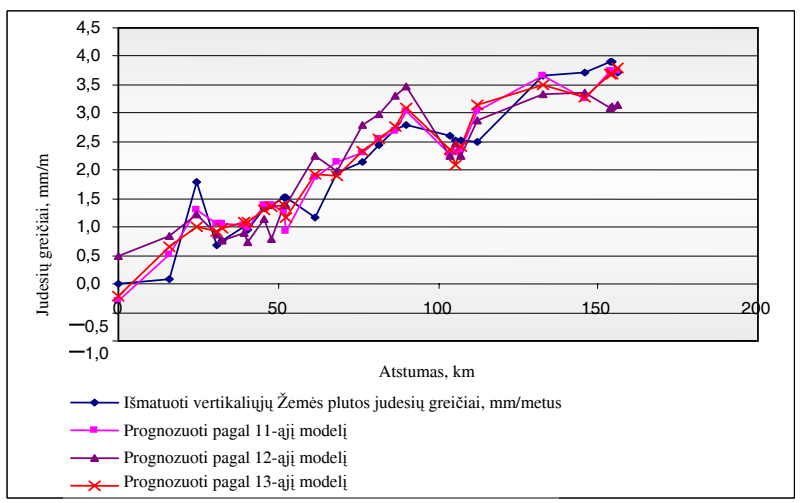

2 pav. Išmatuotų ir prognozuotų vertikaliujų Žemès plutos judesių linijoje Jonava - Zarasai - Turmantas grafikas (pagal 2005-1980 m. matavimo duomenis)

Fig 2. The graphs of measured and forecasted vertical earth crust movements at a line of Jonava - Zarasai - Turmantas (according to the data of 2005-1980)

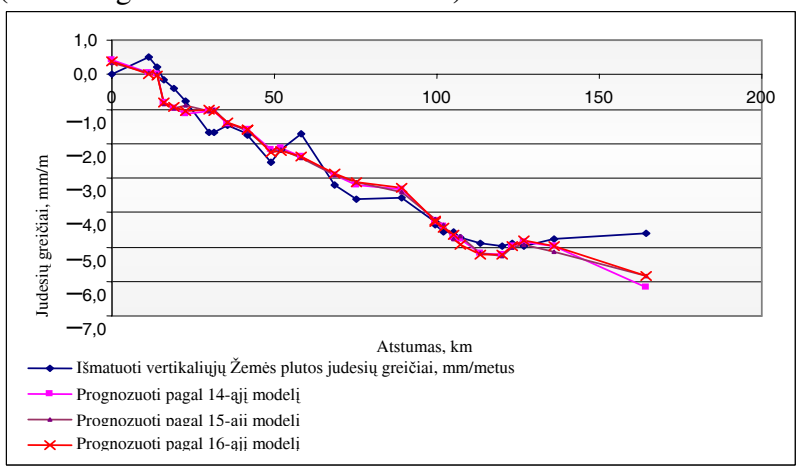

3 pav. Išmatuotų ir prognozuotų vertikaliujų Žemès plutos judesių linijoje Turmantas - Vilnius grafikas (pagal 2005/061985/87 m. matavimo duomenis)

Fig 3. The graphs of measured and forecasted vertical earth crust movements at a line of Turmantas - Vilnius (according to the data of 2005/06-1985/87)

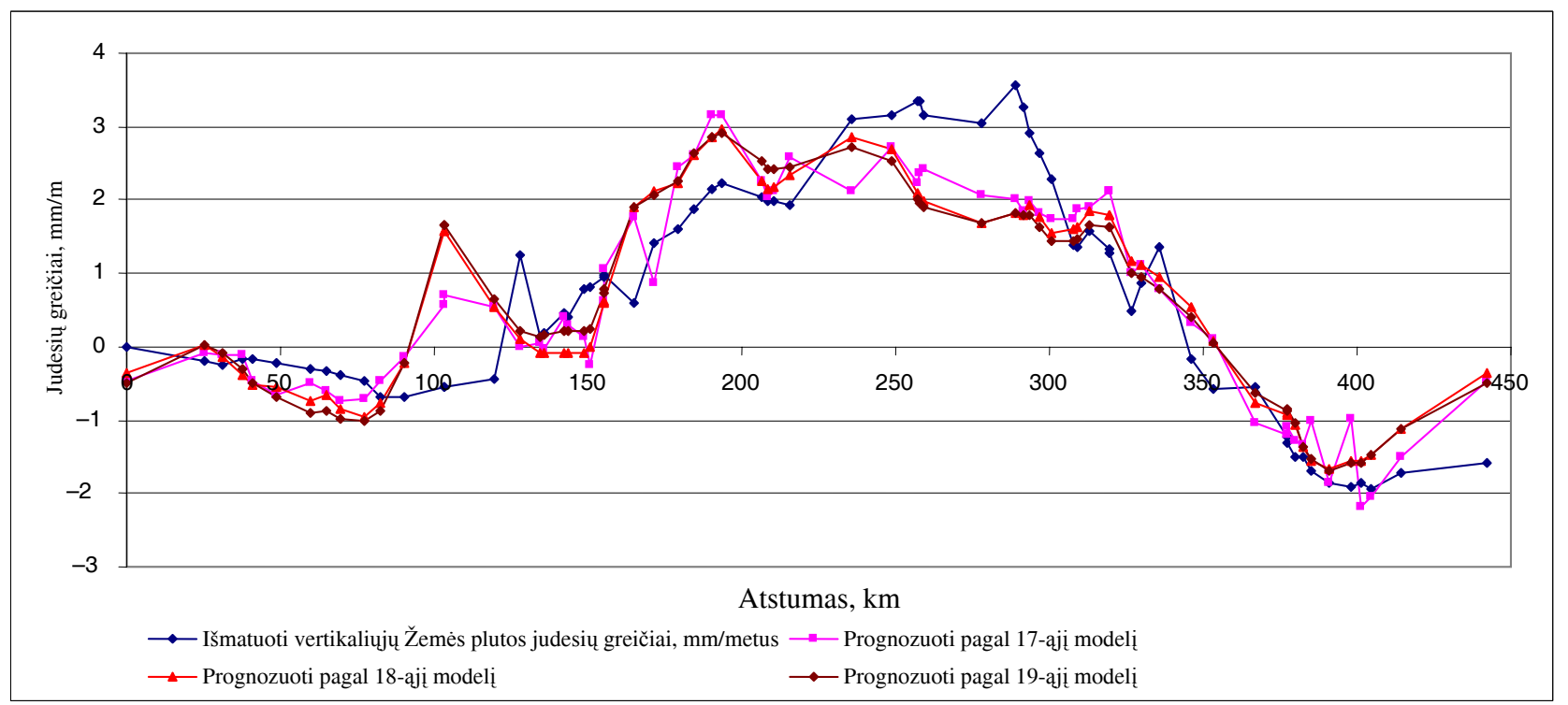

4 pav. Išmatuotų ir prognozuotų vertikaliujų Žemès plutos judesių poligone Vilnius - Jonava - Zarasai - Turmantas - Vilnius grafikas

Fig 4. The graphs of measured and forecasted vertical earth crust movements at a polygon of Vilnius - Jonava - Zarasai Turmantas - Vilnius 


\section{Dabartinių vertikaliụjų Žemės plutos judesiụ Šiaurès Rytų Lietuvoje greičių žemėlapiai, sudaryti pagal regresinius modelius}

Taikant visais trim minètais būdais sudarytus regresinius modelius (3 lentelè, (17-19) modeliai) parengti uždaro poligono Vilnius - Jonava - Zarasai Turmantas - Vilnius, sutampančio su Šiaurès Rytu Lietuvos regionu, vertikaliuju Žemès plutos judesiu greičiu žemèlapiai. Prognozuojant vertikaliuju Žemès plutos judesių greičius, i regresijos lygtis ieinančiu argumentų (geologiniu rodikliu) reikšmès nustatytos iš skaitmeniniu geologiniu duomenu baziu diskrečiuose taškuose, išdèstytuose $5 \times 5 \mathrm{~km}$ kvadratų tinklelio viršūnèse. Žemèlapiai pateikti 5-7 paveiksluose.

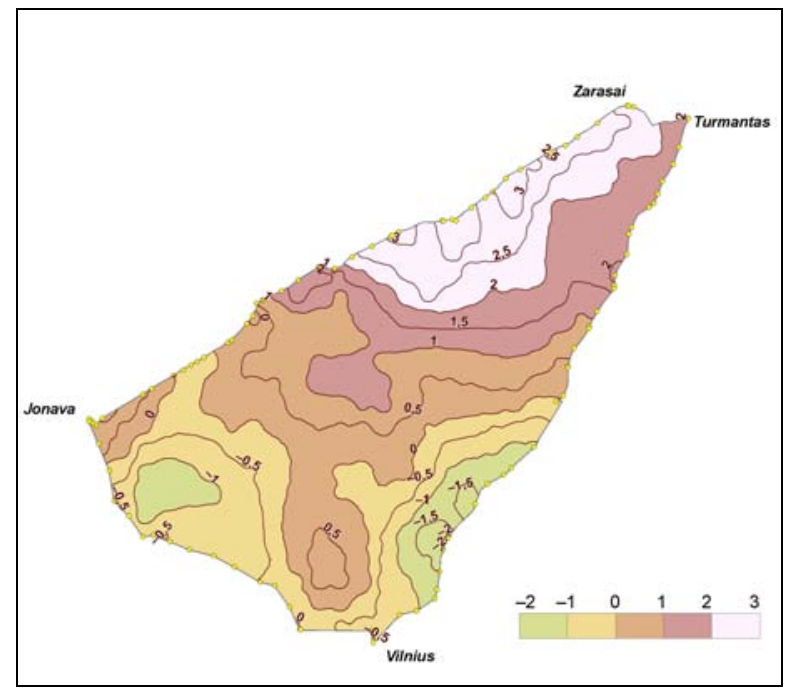

5 pav. Pagal (17) regresini modeli prognozuotas dabartinis tektoninis fonas (judesiu greičiai mm per metus)

Fig 5. The present tectonic background (movements $\mathrm{mm}$ per year) according to the regression model (17)



6 pav. Pagal (18) regresini modeli prognozuotas dabartinis tektoninis fonas (judesių greičiai mm per metus)

Fig 6. The present tectonic background (movements $\mathrm{mm}$ per year) according to the regression model (18)

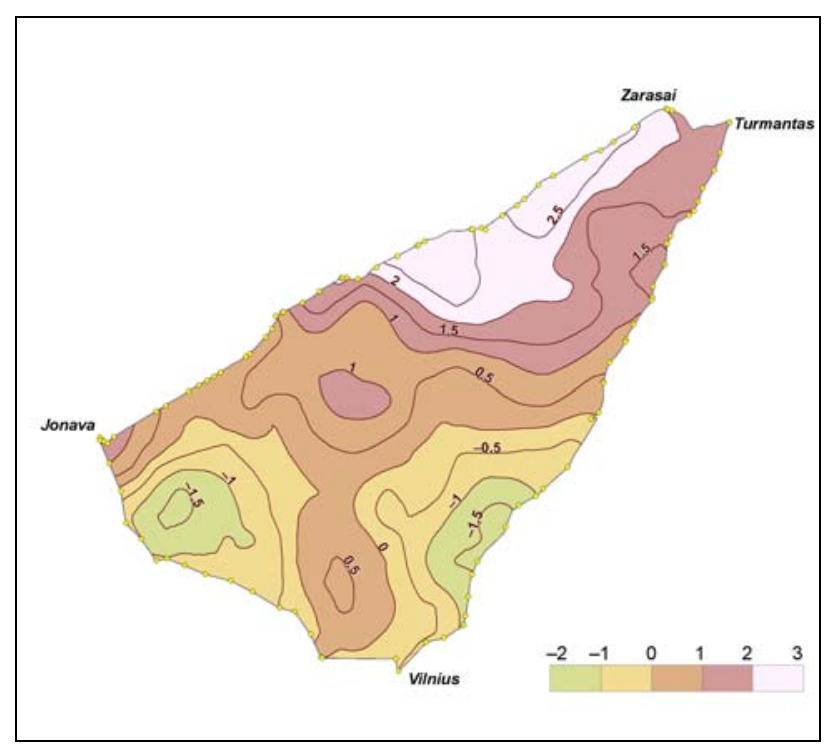

7 pav. Pagal (19) regresini modeli prognozuotas dabartinis tektoninis fonas (judesiu greičiai mm per metus)

Fig 7. The present tectonic background (movements $\mathrm{mm}$ per year) according to the regression model (19)

Iš šiu paveikslų matyti, kad pagal visais trim būdais gautus regresinius modelius sudaryti žemèlapiai labai panašūs ir byloja apie tuos pačius bendruosius dabartinius Žemès plutos judesių dèsningumus, tačiau antruoju atveju (kai taikomi rodikliai, kurių $r \geq 0,50$ ) ir trečiuoju (žingsninè regresija) atveju gaunami labiau suglodinti, t. y. labiau apibendrinti rezultatai. Turint omenyje, kad regresijos modeliuose argumentai yra rodikliai, kuriuos lèmè procesai, trukę ilgus geologinius periodus, o funkcija (dabartiniai Žemès plutos judesiai) nusako, palyginti su argumentais, labai trumpa periodą, netikslinga nagrinejant dabartini teritorijos tektonini foną bei sudarant Žemès plutos judesiu greičiu žemèlapius labai detalizuoti. Rekomenduojame taikyti labiau apibendrintus, t. y. antruoju arba trečiuoju būdu sudarytus regresinius modelius.

\section{Išvados}

1. Nustatytos vertikaliujų Žemès plutos judesių ir teritorijos geologiniu rodikliu koreliacinès priklausomybès. Koreliacinių priklausomybių struktūra priklauso nuo geologinès sandaros regioninių ypatumų ir ne visose nagrinejjamos teritorijos dalyse yra ta pati.

2. Sudaryti Šiaures Rytu Lietuvos teritorijos dabartiniu vertikaliujų Žemès plutos judesių regresiniai modeliai su tikimybe, ne mažesne kaip 0,95 , adekvačiai atkartoja geodeziniais metodais išmatuotu judesiu reikšmes.

3. Dèl geologinių rodiklių tarpusavio koreliaciniu priklausomybių regresinių modelių kintamuju skaičiu galima sumažinti taikant žingsninès regresijos analizès metodika.

4. Kadangi dabartinių Žemès plutos judesių ir teritorijos geologiniu rodikliu koreliacinès priklausomybès ne visur vienodos, nagrinèjant dabartinius Žemès plutos judesius didelèse teritorijose, 
tyrimus būtina diferencijuoti teritoriniu principu pagal regiono geologinę sandarą.

5. Pagal geologinius rodiklius sudaryti dabartiniu Žemès plutos judesių regresiniai modeliai teikia galimybiu prognozuoti Žemès plutos judesius kartotinès niveliacijos poligonu vidineje dalyje, t. y. ten, kur neatliekami tiesioginiai geodeziniai matavimai.

\section{Literatūra}

1. ZAKAREVIČIUS, A. The research of the present vertical Earth's crust movements in Lithuania (Dabartiniu vertikalių Žemès plutos judesių Lietuvos teritorijoje tyrimas). Vilnius: Technika, 1994. 276 p. (in Lithuanian).

2. ZAKAREVIČIUS, A. The research of the present geodynamic processes on the territory of Lithuania (Dabartiniu geodinaminiu procesu Lietuvos teritorijoje tyrimas). Vilnius: Technika, 2003. 195 p. (in Lithuanian).

3. SUVEIZDIS, P. Tectonic structure of Lithuania. Vilnius: Institute of Geology and Geography, 2003. 160 p. (in Lithuanian).

4. ILGINYTE, $\mathrm{V}$. The seismic active tectonic areas of Lithuania. Geologija, 1998, No 23, p. 61-64 (in Lithuanian).

5. RANDJARV, J. Vertical movements of the Earth's crust in the Baltic Region. Reports of the Finish Geodetic institute, 1993, 93(2), $38 \mathrm{p}$.

6. ŽELNIN, G. O. The trustiness of the maps (schemes) of the Earth's crust movement speeds (based on the example of Baltic territory maps). In The Modern Movements of Baltic Territory. Tartu, 1975, p. 13-27 (in Russian).

7. ŠLIAUPA, S.; ZAKAREVIČIUS, A.; STANIONIS, A. Strain and stress fields in the Ignalina NPP area from GPS data and thin-shell finite element modelling. Geologija, 2006, Vol 56, p. 27-35 (in Lithuanian).
8. ZAKAREVIČIUS, A. The results of investigation of vertical movements of the Earth's Crust in Ignalina Nuclear power plant geodynamic polygon. Geodezija ir kartografija, 1997, No 1 (25), p. 78-85 (in Lithuanian).

9. ZAKAREVIČIUS, A.; ANIKĖNIENĖ, A. Peculiarities of present geodynamic processes in the North-eastern Lithuania. In Baltic Surveying'07: Transactions of the Estonian University of Life Sciences. May 9-11, 2007/ Ministry of Agriculture of Lithuania, Lithuanian University of Agriculture. Tartu, 2007, No 224, p. 122-147. ISSN 1406-4049.

10. MARTIŠIUS, S. A.; KĖDAITIS, V. Statistics, part II. The conclusions and solutions of statistics. Vilnius: VU publishing, 2004. 341 p. (in Lithuanian).

Algimantas ZAKAREVIČIUS. Professor, Doctor Habil Dept of Geodesy and Cadastre, Vilnius Gediminas Technical University, Saulètekio al. 11, LT-10223 Vilnius, Lithuania, $\mathrm{Ph}+3705274$ 4703, e-mail:

Algimantas.Zakarevicius@ap.vgtu.lt.

A graduate of Kaunas Polytechnic Institute (now Kaunas University of Technology), geodetic engineer, 1965. Doctor's degree at Vilnius University, 1973. Dr Habil degree at VGTU, 2000. Member of the Geodetic Commission of Estonia, Latvia and Lithuania. Research training at Geodetic Institute of Norwegian Mapping Authority, 1994. Author of over 200 publications and 3 monographs.

Research interests: investigations of the recent geodynamic processes, formation of geodetic networks.

Asta ANIKÉNIENÉ. Doctoral student. Dept of Geodesy and Cadastre, Vilnius Gediminas Technical University, Sauletekio al. 11, LT-10223 Vilnius, Lithuania, Ph +370 5274 4703, e-mail: asta@ap.vgtu.lt.

MSc (2000).

Research interests: investigation of geodynamic processes, GIS, investigations into deformations. 